\title{
Histological and immunohistochemical study on the effect of zinc oxide nanoparticles on cerebellar cortex of adult male albino rats
}

\section{Original Article}

Heba M. Abdel-Aziz, Noura H. Mekawy and Nahla E. Ibrahem

Department of Histology and Cell Biology, Faculty of Medicine, Zagazig University

\begin{abstract}
Background: Zinc oxide nanoparticles (ZnONPs) are one of metal nanoparticles that have widespread use in many fields. Objective: To investigate the effect of ZnONPs on cerebellar cortex of rats through histological and immunohistochemical study.

Materials and methods: Thirty adult male albino rats were divided into three groups; group I (control), Group II (ZnONP-1 treated group) which received orally $50 \mathrm{mg} / \mathrm{kg}$ of ZnONP for two months and Group III (ZnONP-1I treated group) which received orally $200 \mathrm{mg} / \mathrm{kg}$ of ZnONP for two months. Specimens of the cerebellar cortex were processed for histological and immunohistochemical study. Morphometric and statistical analysis were carried out.

Results: Group II showed Purkinje cells were crowded in many layers surrounded by perineuronal vacuoles and had pyknotic nuclei. They had cytoplasmic vacuoles and perinuclear Golgi apparatus revealed fragmented dilated cisternae. Nearby Bergmann astrocyte cells had highly vacuolated cytoplasm and the nerve fibers were also affected and showed dysmyleination (disrupted myelin sheath). Immunohistochemical study of the same group showed Purkinje cell cytoplasm had positive immunoreactions for calretinin proteins. In group III, there was a wide spread of neuronal affection to the degree of loss of many of Purkinje cells leaving empty spaces. Ultrastructurly, their cytoplasm appeared with multiple variable sized and had dilated mitochondria with disrupted cristae. The Bergmann astrocytes revealed nuclei with disrupted nuclear envelope and nearly absence their cytoplasmic organelle and there was more affection to the nerve fibers in the form of vacuolated axoplasm and demyelination (areas of myelin loss) beside dysmyleination. Immunohistochemical study of group III showed Purkinje cells cytoplasm with negative immunoreactions for calretinin proteins.

Conclusion: Intake of ZnONPs induced various adverse alterations in the histological and immunohistochemical structures of cerebellar cortex indicating the occurrence of neurotoxicity. These changes were exaggerated with increasing the dose of their intake.
\end{abstract}

Received: 12 September 2018, Accepted: 31 October 2018

Key Words: Cerebellar cortex, histology, rat, toxic, zinc oxide nanoparticles,

Corresponding Author: Heba M. Abdel-Aziz, MD, Department of Histology and Cell Biology, Faculty of Medicine, Zagazig University, Zagazig, Egypt, Tel.: +20 1281547665, E-mail: hebaeraky37@gmail.com

ISSN: 1110-0559, Vol. 42, No. 1

\section{INTRODUCTION}

Nanoparticles (NPs) are new forms of materials with a size less than $100 \mathrm{~nm}$ have been synthesized by nanotechnology ${ }^{[1]}$. They have unique properties regarding: nano size, nano surface, dissolution, self- assembly, nano structure, concentration and aggregation ${ }^{[2]}$. Over 1000 different manufactured NPs were developed and introduced into the market and one of them was Zinc oxide nanoparticles $(\mathrm{ZnONPs})^{[3]}$. They have received considerable attention due to their low production cost, ability to form diverse structures. Recently, they have been using in various biological applications including drug delivery, bioimaging probes and cancer treatment and as immunomodulatory agent ${ }^{[4 \& 5]}$. They are also widely utilized in industrial field such as electronics, cosmetics, personal care products and food packaging ${ }^{[6 \& 7]}$.

ZnONPs are detected in the water supply due to their environmental release within industrial and domestic discharge ${ }^{[8]}$ so humans become more exposed to them via many routes like ingestion, inhalation and dermal penetration ${ }^{[6]}$. As they have small size so can pass the physiological barriers of the body and widely distributed in the circulation ${ }^{[9]}$. Previous studies reported that ZnONPs have induced obstructive pulmonary diseases $^{[10]}$, hepatotoxicity ${ }^{[1]}$ and nephrotoxicity ${ }^{[12]}$ in animals. Furthermore, the genotoxicity of ZnONPs has been reported as they cause severe DNA damage in peripheral blood and bone marrow cells as evident by chromosomal fragmentation, Moreover, they inhibited DNA repair mechanism by downregulating the expression of proteins ${ }^{[13]}$. Additionally, they cause cytotoxicities in many cultured cells, such as epidermal cells, macrophages, human lung epithelial cells and vascular endothelial cells $^{[14]}$. Some researchers mentioned that ZnONPs in the environment may represent important risk factors for neurodegenerative diseases including Huntington's disease and Alzheimer's disease ${ }^{[15]}$. 
There are many studies mentioned that NPs can reach the brain via the blood-brain barrier (BBB) penetration after oral administration or translocation along the olfactory nerve pathway and subsequently cause neurological affection $^{[16 \& 17]}$. They subsequently induce changes in the spatial learning and memory ability of rats by altering the synaptic plasticity ${ }^{[18]}$. The cerebellum is a critical part of the hind brain and has been known to perform several functions such as cognition, attention and emotional responses in addition to motor coordination and learning ${ }^{[19]}$.

Calretinin is a protein that plays an important role in the controlling processes of cellular calcium and has an anti-apoptotic action ${ }^{[20]}$. Calretinin immunoreaction is expressed in certain cerebellar cells and fibers as unipolar brush cells, mossy fibers and climbing fibers ${ }^{[21]}$. Calcium-binding proteins are important in presynaptic and postsynaptic signaling ${ }^{[22]}$ and that is essential in protection of the brain from injury ${ }^{[23]}$. Other studies ${ }^{[6]}$ focused on the effect of ZnONPs on brain and spinal cord and postulated that they are the main affected nervous components in ZnONPs toxicity. So the present study aimed to investigate the possible effect of ZnONPs oral intake by two different doses on the histological structure of cerebellar cortex of adult male albino rats and to study the changes of calretinin proteins immunoexpression in cerebellar cortex layers.

\section{MATERIALS AND METHODS}

\section{Chemicals}

Zinc oxide nanoparticles (ZnONPs) (cat\# 721077 as dispersion) was obtained from (Sigma-Aldrich, Steinheim, Germany) in the form of white liquid dispersion with the following properties: concentration $50 \mathrm{wt}$. \% in $\mathrm{H} 2 \mathrm{O}$, the average NP size $<35 \mathrm{~nm}$, the particle size distribution (hydrodynamic diameter) $<100 \mathrm{~nm}$ using dynamic light scattering technique, $\mathrm{pH} 7 \pm 0.1$ (for aqueous systems) and density $1.7 \mathrm{~g} / \mathrm{mL} \pm 0.1 \mathrm{~g} / \mathrm{mL}$ at $25^{\circ} \mathrm{C}$. Average diameters of $\mathrm{ZnO}$ NPs were presented in (Figure 1).

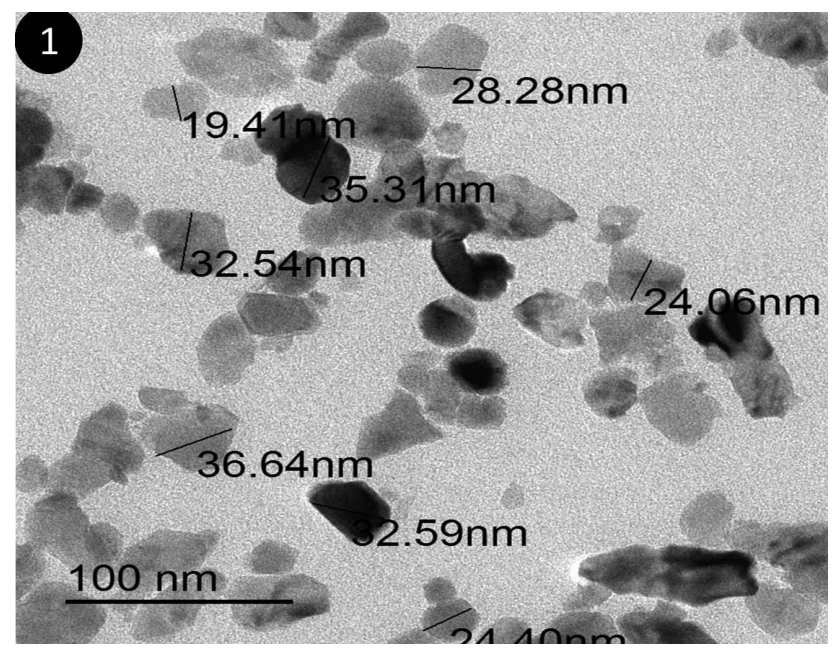

Fig. 1: Transmission electron micrograph (TEM) of ZnONPs' suspension showing that most of the nanoparticles are spherical in shape with diameter $<100 \mathrm{~nm}$.

\section{The experimental animals}

Thirty healthy adult male albino rats ( 9 weeks old) with average weight 200-250 g were used in this experiment. They were housed in stainless steel cages at animal house of Faculty of Medicine, Zagazig University. They were housed at room temperature, fed standard balanced diet and allowed water ad-libitum. All experimental procedures were carried out in accordance with the research protocols established by the Animal Care Committee of the National Research Center (Cairo, Egypt). This research center follows the recommendations of the National Institutes of Health Guide for Care and Use of Laboratory Animals. The rats were allowed to adjust to their new surrounding environment for 5 days.

\section{The experimental protocol}

\section{Rats were randomly divided into 3 groups:}

Group I (Control group): (10 rats), further subdivided into two equal subgroups (five rats each):

Subgroup Ia (Negative control group): were administered no treatment till the end of the experiment.

Subgroup Ib (Positive control group; saline): were administered $0.5 \mathrm{ml}$ saline daily via oral gavage for two months. The saline is the solvent of zinc oxide nanoparticles.

Group II (ZnONP-1 treated group): (10 rats) were administered $50 \mathrm{mg} / \mathrm{kg}$ of ZnONPs dissolved in $0.5 \mathrm{ml}$ saline via oral gavage once daily for two months ${ }^{[6]}$.

Group III (ZnONP-2 treated group): (10 rats) were administered $200 \mathrm{mg} / \mathrm{kg}$ of ZnONPs dissolved in $0.5 \mathrm{ml}$ saline via oral gavage once daily for two months ${ }^{[6]}$.

The animals were examined daily for neurological signs by naked eye in their cages. At the end of the experiment, the rats from all groups were fasted overnight. They were anesthetized with intraperitoneal injection of 25 $\mathrm{mg} / \mathrm{kg}$ sodium thiopental ${ }^{[24]}$. Intra-cardiac perfusion was carried out through butterfly needle was fixed to the left ventricle of the rat heart till the ascending aorta. Initially the intravascular perfusion by $0.9 \%$ saline solution to clear the blood from the body then used $2.5 \%$ glutaraldehyde in $0.1 \mathrm{~mol} / \mathrm{L}$ cacodylate buffer $(\mathrm{pH}$. 7.3) for partial fixation of cerebellum. After completing the perfusion process, the skull was opened and the cerebellum of all animals was excised to obtain the intact cerebellar lobules, a midsagittal section of the cerebellar vermis was made. A part of cerebellar lobule were excised, cut into smaller pieces and processed for light and electron microscopic study ${ }^{[25]}$.

For light microscopy; specimens of the cerebellar cortex were immersed in 10\% neutral-buffered formalin for $24 \mathrm{~h}$, washed, dehydrated, cleared embedded in paraffin. Then, $5 \mu \mathrm{m}$ sections were prepared. Some of these sections were stained with haematoxylin and eosin $(\mathrm{H} \& \mathrm{E})^{[26]}$. The other paraffin-embedded sections were immunohistochemically stained using the avidin-biotin peroxidase system for the 
detection of calretinin (Cas no. 103261; Sigma-Aldrich, Saint Louis, USA). Serial sections of paraffin-embedded specimens were deparaffinized on charged slides and hydrated. They were treated with $0.01 \mathrm{M}$ citrate buffer (PH. 6.0 ) for unmask antigen. Then, they were incubated in $0.3 \%$ hydrogen peroxide for 30 minutes to abolish the endogenous peroxidase activity before blocking with $5 \%$ horse serum for 1-2hrs. The slides sections were incubated at $4 \mathrm{C}$ for $18-$ $20 \mathrm{~h}$ in the Primary antibody (rabbit monoclonal antibody; dilution 1/100; Sigma-Aldrich, Steinheim, Germany). After several washes with phosphate buffer saline (PBS), incubated for two hours with biotinylated secondary antibodies followed by streptavidin - biotin complex. The reactions were visualized with $0.05 \% \mathrm{DAB}$ as a chromogen. Slides were counter stained with hematoxlyin, dehydrated, clear and mounted ${ }^{[27]}$. The positive immunoreaction of calretinin appeared as brown cytoplasmic reaction in the cells cytoplasm and fibers of cerebellar cortex but Purkinje cells show negative immunoreaction ${ }^{[20]}$.

For electron microscope; cerebellar specimens were fixed in fresh $3 \%$ glutaraldehyde (pH. 7, 4), post fixed in $1 \%$ osmium tetroxide in the same buffer at $4{ }^{\circ} \mathrm{C}$, dehydrated and embedded in epoxy resin. Ultrathin sections were obtained (Leica ultracut UCT), stained with uranyl acetate and lead citrate ${ }^{[28]}$. The copper grids were examined and photographed using a JEOL JEM 2100 electron microscope (Jeol Ltd, Tokyo, Japan) in Electron Microscope Research Laboratory (EMRL) of Faculty of Agriculture, El Mansoura University, Egypt.

\section{Morphometric study}

Leica Qwin 500 image analyzer computer system (Leica Ltd, Cambridge, UK) at the Image Analyzing Unit of Pathology Department, Faculty of Dentistry, Cairo University, Egypt was used. The area percent of calretinin immunoreaction was measured using the interactive measure menu. The measuring frame of a standard area equal to $118476.6 \mathrm{~mm}^{2}$ was chosen so that the brown positive immunoreaction could be seen and masked by blue binary colour to be measured. Ten readings from five non-overlapping sections from each rat of all groups were examined.

\section{Statistical analysis}

All data were expressed as mean \pm SD using the Statistical Package for the Social Sciences (SPSS) software, version 13.00 (Chicago, Illinois, USA). Statistical significance was determined by one-way analysis of variance (ANOVA) for differences between the means of different groups. Further analysis was carried out using the post-hoc test to compare the parameters between the different groups with each other. Probability of P less than 0.05 was considered statistically significant and highly significant when the $P$ values were less than 0.001

\section{RESULTS}

\section{General examination:}

The rats in group I (subgroups, Ia and $\mathrm{Ib}$ ) appeared normal and did not exhibit any signs of neurological abnormality. On the other hand, rats from group II exhibited some neurological signs in the form of reduction in activity, muscle weakness, tremors with movement and loss of equilibrium. At the end of the experiment their hind limbs were paralysed. These signs were exaggerated in Group III that received $200 \mathrm{mg} / \mathrm{kg}$ of ZnONPs.

\section{Histological results:}

The control subgroups Ia and Ib revealed nearly similar histopathological results; consequently, only results of the control subgroup Ia were presented.

Examination of the H\&E-stained sections of group I revealed normal histological structure of the cerebellar cortex. The cortex which constituted the grey matter of cerebellum was formed of three layers; outer molecular, middle Purkinje and inner granular layers. The outer molecular layer consisted of nerve cells with vesicular nuclei and blood vessels. The Purkinje layer showed large flask shaped Purkinje cells arranged typically in a single row at the junction of the molecular and the granular layers. These Purkinje cells displayed characteristic centrally located rounded open face nuclei and they were surrounded by Bergmann astrocytes cells with vesicular nuclei. The inner granular cell layer contained numerous small granule cells with deeply stained nuclei (Figure 2a). In group II, H\&E sections revealed the molecular layer had nerve cells with darkly stained nuclei and its neuropils were degenerated. The Purkinje cell layer appeared crowded in many layers. Some of them were displaced upwards in the molecular layer while others displaced downwards in the granular cell layer. Also, the Purkinje cells were surrounded by perineuronal vacuoles and had pyknotic nuclei. Moreover, the granular layer had granule cells with pyknotic nuclei (Figure $2 \mathrm{~b}$ ). In group III, there was a wide spread of neuronal affection to the degree of loss of many of Purkinje cells leaving empty spaces and the Purkinje cells appeared were highly distorted and pyknotic. Moreover, Granule cells appeared scattered and few in number with pyknotic nuclei (Figure 2c).

The immunohistochemical study of group I showed that there were positive immunoreactions of calretinin proteins in the fibers of molecular layer, Bergmann astrocytes and granular cells. However, the cytoplasm of Purkinje cells showed a negative immunoreaction (Figure 3a). On the other hand, in group II, the cytoplasm of Purkinje cells had a positive immunoreaction for calretinin proteins (Figure 3b). In group III, Purkinje layer expressed negative reactions for calretinin while molecular and granular layer showed weak positive reactions (Figure $3 \mathrm{c}$ ). 
Ultrastructurally, group I revealed Purkinje cells had large indented euchromatic nuclei. Their cytoplasm contained numerous mitochondria, scattered cisternae of rough endoplasmic reticulum and free ribosomes (Figure 4a). In group II, Purkinje cells appeared shrunken and their nuclei showed condensed heterochromatin. Their cytoplasm was electron dense and had vacuoles and fragmented dilated cisternae of perinuclear Golgi apparatus (Figure $4 \mathrm{~b}$ ). The Purkinje cells of group III were more shrunken and had, denser cytoplasm which showed multiple variable sized vacuoles and dilated mitochondria with disrupted cristae. Their nuclei were heterochromatic with irregular nuclear envelope (Figure 4c).

Bergmann astrocytes of group I appeared ensheathed Purkinje cells with their processes and had euchromatic nuclei and pale cytoplasm containing ribosomes, mitochondria, lysosomes and rough endoplasmic reticulum (Figure 5a). In group II, Bergmann astrocytes had highly vacuolated cytoplasm (Figure 5b). In group III, the cells appeared with nuclei had disrupted nuclear envelope and nearly absence of their cytoplasmic organelles (Figure 5c).

The granular layer of cerebellar cortex in group I showed closely packed spherical nuclei of granule nerve cells with their characteristic condensed chromatin, the nuclei were surrounded by very little cytoplasm contained strands of rough endoplasmic reticulum, free ribosomes and mitochondria. In-between granular cells, there were scattered myelinated nerve fiber showing compact lamellar structure of myelin around smooth contoured axons (Figure 6a). In group II, the granule cells had heterochromatic nuclei with irregular nuclear envelope and some cells showed vacuolated cytoplasm. The myelinated nerve fibers showed dysmyleination in the form of focal areas of splitting of myelin sheath. Vacuolation of neuropil in granular layer was also noticed (Figure 6b). In group III, there was more affection of granular layer including nerve fibers with vacuolated axoplasm, some fibers showed demyelination (areas of myelin loss) and others showed dysmyleination. The granule cells had heterochromatic nuclei with irregular nuclear envelope whereas the neuropil showed numerous vacuolation (Figure 6c).

\section{Morphometric results}

Immunohistochemical study of calretinin proteins in the present work revealed an interesting pattern of expression of them in Purkinje cells. In group II, Purkinje cells showed a highly significant increase in calretinin immunoreaction as compared to group I. However, in group III they showed a highly significant decrease in the reaction compared to group II (Table 1).
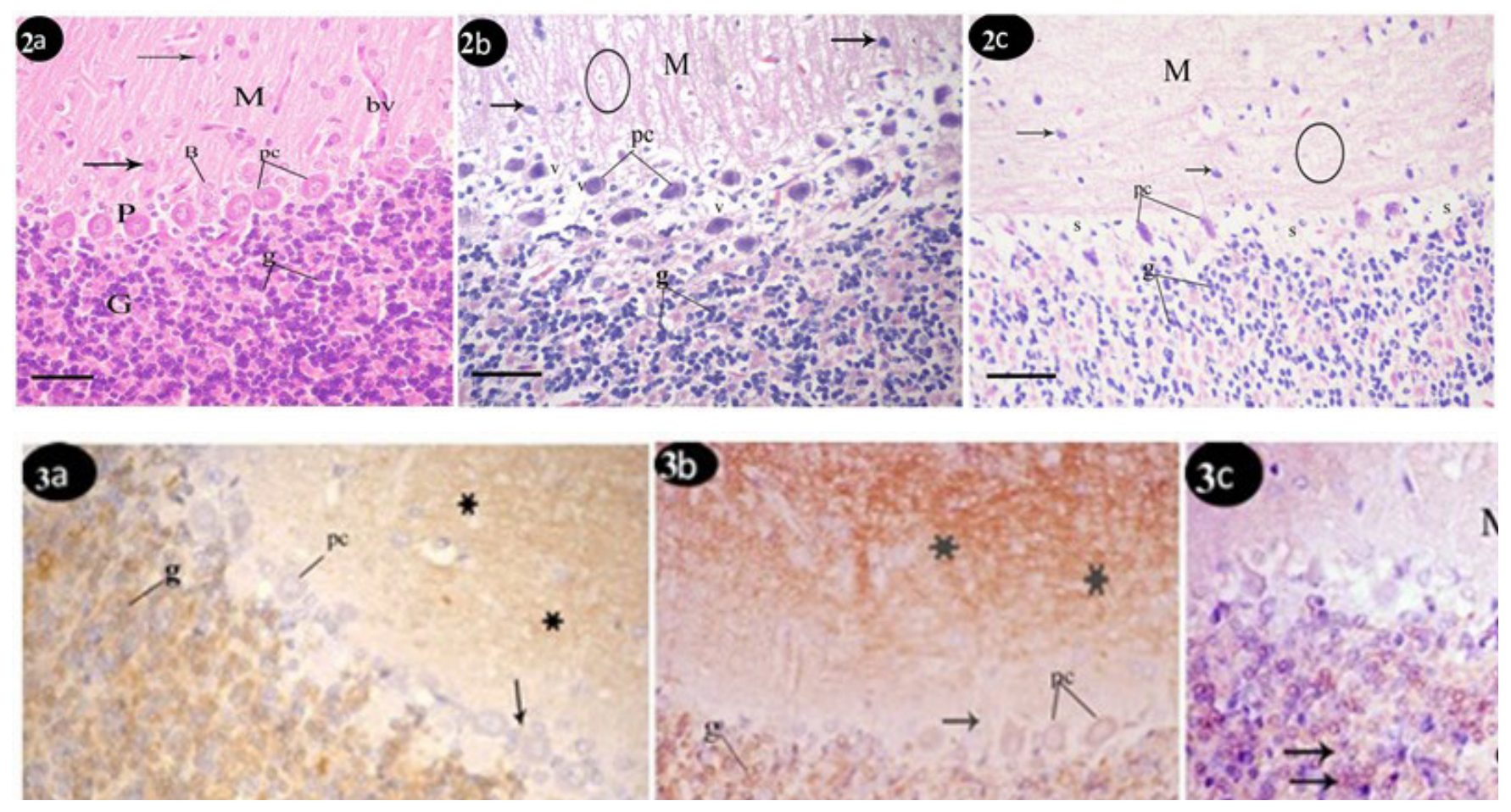


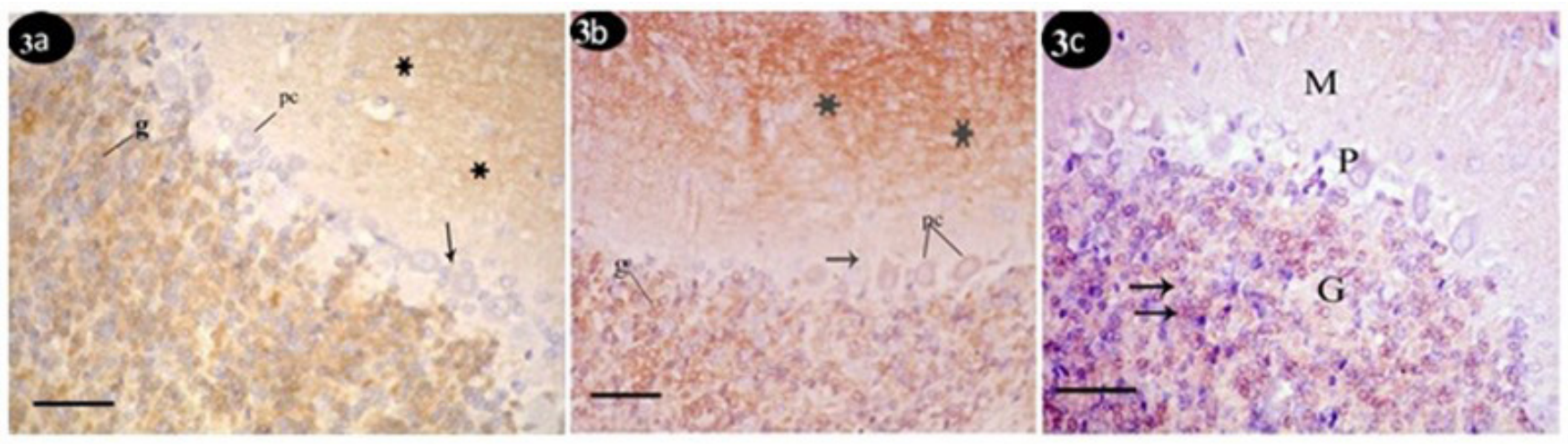

Fig. 3: A photomicrograph of immunohistochemical reactions of calretinin proteins in sections of cerebellar cortex

(3a): Group I showing a positive immunoreaction in fibers of the molecular layer (asterisks), Bergmann astrocyte (arrow) and granular cells (g). There is a negative reaction in Purkinje cell cytoplasm (pc).

(3b): Group II showing a positive reaction in Purkinje cells cytoplasm (pc). Also, positive immunoreactions are detected in the fibers of the molecular layer (asterisk), Bergmann astrocyte (arrow) and granular cells (g).

(3c): Group III showing Purkinje layer (P) with negative reactions while molecular (M) and granular (G) layers showing weak positive reactions.

(Immunoperoxidase technique for calretinin, scale bar $30 \mu \mathrm{m}$ )
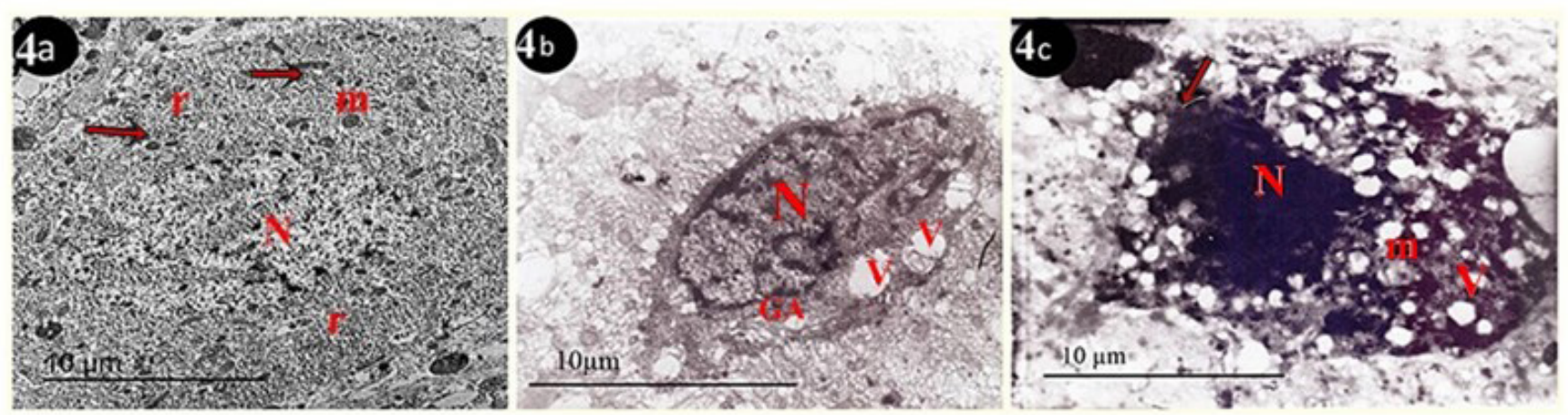

Fig. 4: An electron micrograph of Purkinje cells

(4a): Group I showing a large indented, euchromatic nucleus $(\mathrm{N})$. Its cytoplasm contains numerous mitochondria (m), scattered cisternae of rough endoplasmic reticulum (arrows) and free ribosomes (r).

(4b): Group II showing a shrunken Purkinje cell having a nucleus $(\mathrm{N})$ with condensated chromatin. Its cytoplasm is electron dense and has fragmented and dilated cisternae of perinuclear Golgi apparatus (GA) and cytoplasmic vacuoles (v).

(4c): Group III showing a Purkinje cell with heterochromatic nucleus (N) and nuclear irregular nuclear envelope (arrow). The cytoplasm is electron dense and has multiple variable sized vacuoles (v) and dilated mitochondria with disrupted cristae (m).
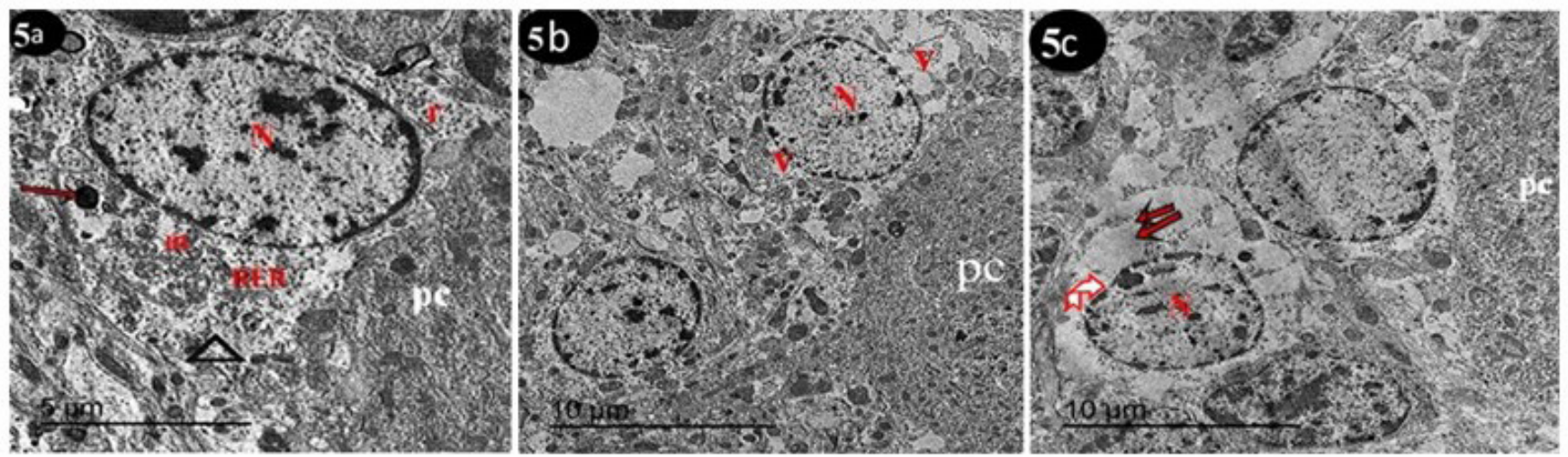

Fig. 5: Electron micrograph of cerebellar cortex

(5a): Group I showing a Bergmann astrocyte ensheathing a Purkinje cell (pc) with their processes $(\Delta)$. It has euchromatic nucleus $(\mathrm{N})$ and pale cytoplasm contains ribosomes (r), mitochondria (m), lysosome (arrow) and rough endoplasmic reticulum (RER).

(5b): Group II showing a Bergmann astrocyte near a Purkinje cell (pc) which has euchromatic nucleus $(\mathrm{N})$ and highly vacuolated cytoplasm (v)

(5c): Group III showing a Bergmann astrocyte beside a Purkinje cell (pc), which has a nucleus $(\mathrm{N})$ with disrupted nuclear envelope (curved arrow) and nearly no cytoplasmic organelles (double arrows). 

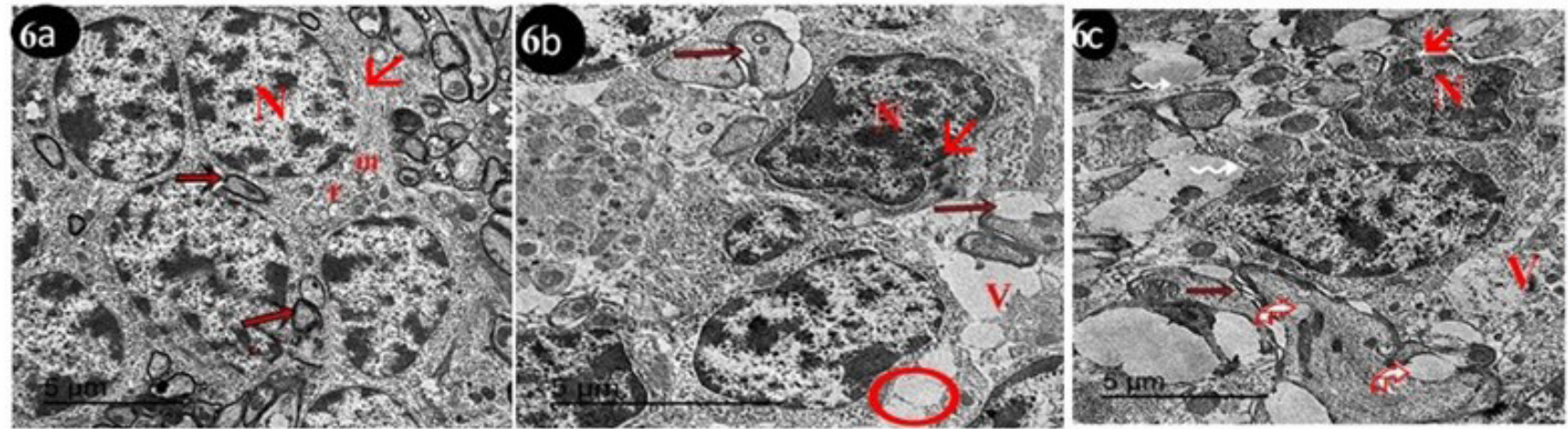

Fig. 6: An electron micrograph of a section in the cerebellar cortex

(6a): Group I showing granule cells with their spherical nuclei with their characteristic condensed chromatin (N) surrounded by a shell of cytoplasm has strands of rough endoplasmic reticulum (arrow head), free ribosomes ( $r$ ) and mitochondria (m). Myelinated nerve fibers have regular compact myelin sheath (arrows) are also seen.

(6b): Group II showing a granule cells with heterochromatic nucleus (N) and irregular envelope (arrowhead). The cytoplasm of some granule cells show vacuolation (circle). Some nerve fibers have focal areas of splitting of myelin sheath (arrows) and vacuolated neuropil (V) in granular layer is also seen. (6c): Group III showing nerve fibers with vacuolated axoplasm (curved arrows) and some of them showed areas of myelin loss (zigzag arrows). Others, with focal areas of splitting of myelin sheath (arrow). The granule cell appears with heterochromatic nucleus (N) and irregular envelope (arrowhead) and highly vacuolated neuropil (V) inbeween granular cells).

Table 1: Mean values \pm S.D of $\%$ area of calretinin immune-stain in the different studied groups.

\begin{tabular}{|c|c|c|c|c|}
\hline & Group I & Group II & Group III & Significance \\
\hline \multirow{3}{*}{ Molecular layer } & \multirow{3}{*}{$14.4800 \pm 2.4760$} & \multirow{3}{*}{$14.9300 \pm 1.6720$} & \multirow{3}{*}{$3.7000 \pm 2.3333$} & $\mathrm{P} 1=0.8622$ \\
\hline & & & & $\mathrm{P} 2<0.0001^{*}$ \\
\hline & & & & $\mathrm{P} 3<0.0001 *$ \\
\hline \multirow{4}{*}{ Purkinje cell layer } & \multirow{4}{*}{$1.7700 \pm 2.2642$} & \multirow{4}{*}{$12.1100 \pm 1.2215$} & \multirow{4}{*}{$9.2600 \pm 1.0069$} & $\mathrm{P} 1<0.0001 *$ \\
\hline & & & & $\mathrm{P} 2<0.0001^{*}$ \\
\hline & & & & $\mathrm{P} 3<0.0001^{*}$ \\
\hline & & & & $\mathrm{P} 1=0.0922$ \\
\hline \multirow[t]{2}{*}{ Granular layer } & \multirow[t]{2}{*}{$21.4000 \pm 1.8547$} & \multirow[t]{2}{*}{$19.5800 \pm 1.2453$} & \multirow[t]{2}{*}{$5.9200 \pm 2.1948$} & $\mathrm{P} 2<0.0001 *$ \\
\hline & & & & P3 $<0.0001$ \\
\hline
\end{tabular}

*= highly significant change $(P<0.0001)$ by student $t$-test.

$\mathrm{P} 1=$ comparison between group I and group II

P2 = comparison between group I and group III

P3 = comparison between group II and group III. 


\section{DISCUSSION}

Zinc oxide nanoparticles (ZnONPs) have gained great attention owing to their rapidly increasing use in many fields, including Nanomedicine as in trials for treating cancer. Human exposure to them occurred via many routes, including: ingestion, inhalation, injection and dermal penetration ${ }^{[29]}$.

Some studies considered zinc nanoparticles safe due to the presence of Zinc as trace element in the human body ${ }^{[30]}$. However, in spite of their wide application, the hazards of their exposure are not yet known and many researchers studied their effects on many organs like liver, heart, submandibular gland, bone and pancreas ${ }^{[31]}$. This study investigated the neurological effects of ZnONPs on cerebellar cortex through histological and immunohistochemical studies on adult male albino rats.

In the current work, the choose of oral intake of ZnONPs because humans have a higher chance of ingestion of them in the food-related products with different doses ${ }^{[32]}$. Zinc ion concentration is increased in plasma after daily oral administration of ZnONPs and deposited in the different organs, after a period of 28 days ${ }^{[33]}$.

In the present study, the control group revealed the observations correlated with the histological organization of the normal cerebellum structure as reported by previous study ${ }^{[34]}$. In group II that were treated with $50 \mathrm{mg} / \mathrm{kg}$ showed disturbed normal linear organization of Purkinje cell layer due to crowding of Purkinje cells. Some cells were displaced upwards in the molecular layer while others were displaced downwards in the granular cell layer. This multilayer deposition of Purkinje cells was explained by exposure to neuronal insult that could lead to adaptive response in the form of crowding of Purkinje cells in a trail to reestablish the synaptic contact with other neurons in order to perform their function ${ }^{[35]}$. One the other hand, group III that were treated by $200 \mathrm{mg} / \mathrm{kg}$ revealed nearly absence of Purkinje cells in many areas leaving empty spaces and these results were in agreement with previous authors $^{[6]}$

Purkinje cells in group II were appeared surrounded by perineuronal spaces and highly distorted in group III. These results were attributed to shrinkage of Purkinje cells and withdrawal of their protoplasmic processes secondary to disintegration of cytoskeletal elements ${ }^{[36]}$.

The electron microscopic study revealed Purkinje cells in group II had electron dense cytoplasm that contained dilated cisternae of Golgi apparatus. The cytoplasm of Purkinje cells in group II was denser than in group II. Those results were in agreement with previous researchers [6] who reported that ZnONPs caused considerable damage to the cytoplasmic organelles concerned with the biosynthesis of cell proteins.

Previous researchers ${ }^{[37]}$ mentioned that the presence of dark neurons in various regions of the grey matter of CNS was usually due to ischemic action on the capillary wall of the cerebellar cortex. Others ${ }^{[36]}$ explained the appearance of dark neurons by a certain phase of apoptosis.

The treatment with higher doses of NPs was found to induce apoptosis and autophagy in mammalian cells ${ }^{[13]}$. On the contrary, other researchers ${ }^{[38]}$ proved that long term exposure to 50 and $500 \mathrm{mg} / \mathrm{kg}$ nano- $\mathrm{ZnO}$ in diets didn't cause toxicity whereas high dose of nano-ZnOs about 5000 $\mathrm{mg} / \mathrm{kg}$ caused toxic effect. Additionally, the current study was in agreement with previous finding ${ }^{[39]}$ which reported a significant cellular toxicity effect of ZnONPs that started at $50 \mathrm{mg} / \mathrm{kg}$ intake and was exaggerated at a dose of $200 \mathrm{mg} /$ $\mathrm{kg}$ by increasing the oxidant status and decreased the antioxidant capacity.

The electron microscopic examination of Bergmann astrocytes of group II revealed many cytoplasmic vacuolation. These results were attributed to a cell pathological change observed in astrocytes against various stimuli ${ }^{[40]}$. Moreover, in group III, nuclei of these cells appeared with disrupted envelopes and the cytoplasm was devoided from organelles. Rafati et al[41] reported that disruption of the architecture of Bergmann glia led to neurodegeneration of cerebellar Purkinje cells. Thus the degeneration of the supporting Bergmann cells in the current study might explain the degeneration and loss of Purkinje cells.

Regarding the vacuolar appearance of cytoplasm of Purkinje cells in group II which was obviously increased in group III. These findings were also detected within the cytoplasm of germ cells and olfactory epithelial cells exposed to $\mathrm{ZnONPs}^{[42]}$. These vacuoles might be a result of cellular swelling caused by failure of the energy-dependent $\mathrm{Na}+\mathrm{K}+$ ion pumps in the plasma membranes as a result of lipid peroxidation ${ }^{[43]}$.

Additionally, the cytoplasm of Purkinje cells in group III revealed mitochondrial alteration in the form of dense matrix and intracrystal destruction. These changes were attributed to degeneration secondary to high metabolic activity of the cell[44].

In the present work, Immunohistochemical study of calretinin proteins revealed that Purkinje cells of group II showing a highly significant increase in calretinin immunoreaction as compared to group I. However, in group III they showed a highly significant decrease in the reaction compared to group II and these results were reported by previous studies ${ }^{[45]}$. In calretinin knockout mice, the cerebellum resulted in unexpected positive calretinin immunoreactivity in Purkinje cells as marked abnormalities in the Purkinje cell firing with modifications of both simple and complex spike ${ }^{[46]}$. The increased immunoreactivity of the Purkinje cells in group II suggested an adaptive mechanism to combat against the neurodegeneration ${ }^{[47]}$. On the other hand, the decrease in the immunoreactivity in group III might be due to the massive degeneration of many Purkinje cells. The neuronal degeneration resulted in a decrease in calretinin expression in the hippocampus and cerebellum as previously reported ${ }^{[48]}$. 
Light microscopic examination of the granular cells of both group I and II showed pyknotic nuclei however in group II, they were scattered and fewer in numbers. Ultrastructurly, the granular neurons had heterochromatic nuclei with irregular nuclear envelopes and some of them had vacuolated cytoplasm in group III. This finding was explained by exposure of cerebellar granular cells to oxidative stress ${ }^{[49,50]}$. Previous investigators ${ }^{[15]}$ suggested that granular cells changes were secondary to alterations occurred in Purkinje neurons leading to gradual loss of synchronization between both nerve cells.

Ultrastructurely, the vacuolation of neuropil in group II which was increased in group III might be due to shrinkage of cells and withdrawal of their processes secondary to cytoskeletal affection as a sign of neuronal death ${ }^{[51]}$.

Ultrathin section examination revealed axonal changes in the form of dysmyelination in group II in addition to vacuolation of axoplasm and occurrence of demyelination in group III. These results were explained by some investigators $^{[51]}$ as axon changes were a component of a dying-back process of neuronal injury while the myelination's disruption was secondary to the changes in myelin basic protein lead to membrane damage and axonal degeneration. Dysmyelination was attributed to increased water content in degenerating nerve causing intramyelinic edema and oedematous splitting at various levels of the myelin lamella ${ }^{[52]}$. Demyelination can occur as a response to axonal degeneration or secondary to the oxidative stress $^{[53]}$. In addition, the free radicals potentially damaged the oligodendrocytes [responsible for myelination) and neurons causing cell membrane damage and impairment of myelination in the axoplasm ${ }^{[54]}$.

The toxicity of ZnONPs was attributed by previous studies ${ }^{[55]}$ to their small size that can penetrate the blood brain barrier (BBB). Once they reach the cell cytoplasm, they can cause direct damage and cell death. Shen et al ${ }^{[56]}$ suggested that intracellular release of ionic $\mathrm{Zn}+2$ from the particles with a subsequent elevation of the cytosolic $\mathrm{Zn} 2+$ concentration which was responsible for cell membrane injuries, triggering inflammatory responses, DNA damage and death of the cells. Such a concept has been supported by other studies ${ }^{[57]}$ which added that the elevation of cytoplasmic Zn2 caused mitochondria to sequester Zn2+ ions and affects the mitochondrial membrane permeability in the form of opening mitochondrial pores and release factors that may trigger the intrinsic pathway of apoptosis.

Oxidative stress occurred even when only small amounts of ZnONPs were combined into the cells. This led to the accumulation of reactive oxygen species (ROS) that attack the DNA, generating a huge range of base and sugar modifications and a number of alterations such as DNA cleavage and oxidation of purines. Induction of ROS can occur spontaneously once ZnONPs are exposed to the acidic medium of lysosomes owing to their chemical and surface nano-level characteristics. These interactions affect the biological system's ability to detoxify the reactive intermediates or to repair the resulting damage ${ }^{[7]}$.

\section{CONCLUSION}

Intake of $\mathrm{ZnONPs}$ induced various adverse alterations in the histological structure of cerebellar cortex indicating the occurrence of neurotoxicity. These changes were exaggerated with increasing the dose of ZnONPs administration. We recommended a reduction of the human exposure to these potentially toxic materials and more research to find cures for diseases associated with nanoparticles exposure.

\section{CONFLICT OF INTEREST}

There is no potential conflict of interest among the authors.

\section{REFERANCES}

1. Torabi F, Shafaroudi MM, Rezaei N. Combined protective effect of zinc oxide nanoparticles and melatonin on cyclophosphamide-induced toxicity in testicular histology and sperm parameters in adult Wistar rats. Int J Repro Biomed 2017; 15(7): 403.

2. Chang YN, Zhang M, Xia L, Zhang J, Xing G. The toxic effects and mechanisms of $\mathrm{CuO}$ and $\mathrm{ZnO}$ nanoparticles. Mate 2012; 5(12):2850-2871.

3. Sabir S, Arshad M, Chaudhari SK. Zinc oxide nanoparticles for revolutionizing agriculture: synthesis and applications. Sci World J 2014; 2014.

4. Premanathan M, Karthikeyan K, Jeyasubramanian $\mathrm{K}$, Manivannan G. Selective toxicity of $\mathrm{ZnO}$ nanoparticles toward Gram-positive bacteria and cancer cells by apoptosis through lipid peroxidation. Nanomed: Nanotech, Bio and Med 2011; 7(2):184-192.

5. Xiong HM. ZnO nanoparticles applied to bioimaging and drug delivery. Adv Mater 2013; 25(37):5329-5335.

6. Elshama SS, El-Kenawy AEM, Osman HEH. Histopathological study of zinc oxide nanoparticleinduced neurotoxicity in rats. Toxicol 2017; 13.

7. Ansar S, Abudawood M, Hamed SS, Aleem MM Exposure to zinc oxide nanoparticles induces neurotoxicity and proinflammatory response: amelioration by hesperidin. Bio Trace Elem Res 2017; 175(2):360-366.

8. Giovanni M, Tay C Y, Setyawati, MI, Xie, J, Ong CN, Fan, R, Yue J, Zhang L, Leong, DT.. Toxicity profiling of water contextual zinc oxide, silver, and titanium dioxide nanoparticles in human oral and gastrointestinal cell systems. Environ toxicol 2015; 30(12):1459-1469. 
9. Cristina B, Ivan I, Pache CO, Robbie K. Nanomaterials and nanoparticles: sources and toxicity. Biointerphases 2007;2(4): MR17-71.

10. Kao YY, Chen YC, Cheng TJ, Chiung YM, Liu PS. Zinc oxide nanoparticles interfere with zinc ion homeostasis to cause cytotoxicity. Toxicol Sci 2011; 125(2): 462-472.

11. Mansouri E, Khorsandi L, Orazizadeh M, Jozi Z. Dose-dependent hepatotoxicity effects of Zinc oxide nanoparticles. Nanomed J 2015; 2(4):273-282.

12. Yan G, Huang Y, Bu Q, Lv L, Deng P, Zhou J, Wang Y, Yang Y, Liu Q, Cen X Zhao Y. Zinc oxide nanoparticles cause nephrotoxicity and kidney metabolism alterations in rats. J Environ Sci Health, Part A 2012; 47(4):577-88.

13. Pati R, Das I, Mehta RK, Sahu R, Sonawane A. Zinc-oxide nanoparticles exhibit genotoxic, clastogenic, cytotoxic and actin depolymerization effects by inducing oxidative stress responses in macrophages and adult mice. Toxicol Sci 2016; 150(2):454-472.

14. Hsiao IL, Huang YJ. Effects of various physicochemical characteristics on the toxicities of $\mathrm{ZnO}$ and $\mathrm{TiO} 2$ nanoparticles toward human lung epithelial cells. Sci Total Environ 2011; 409(7):1219-28.

15. Costa LG, Cole TB, Coburn J, Chang YC, Dao K, Roque P. Neurotoxicants are in the air: convergence of human, animal, and in vitro studies on the effects of air pollution on the brain. BioMed Res Int 2014; 2014: 1-8.

16. Gonzalez-Estrella J, Puyol D, Sierra-Alvarez R, Field JA. Role of biogenic sulfide in attenuating zinc oxide and copper nanoparticle toxicity to acetoclastic methanogenesis. J hazard Mater 2015; 283:755-763.

17. Lee CM, Jeong HJ, Kim DW, Sohn MH, Lim ST. The effect of fluorination of zinc oxide nanoparticles on evaluation of their biodistribution after oral administration. Nanotech 2012; 23(20).

18. Han D, Tian Y, Zhang T, Ren G, Yang Z. Nanozinc oxide damages spatial cognition capability via over-enhanced long-term potentiation in hippocampus of Wistar rats. Int J Nanomed 2011; 6:1453-1461.

19. Parasuram H, Nair B, Naldi G, D’Angelo E, Diwakar S. Understanding Cerebellum Granular Layer Network Computations through Mathematical Reconstructions of Evoked Local Field Potentials. Ann Neurosci 2018; 25(1):11-24.

20. Szalak R, Matysek M, Mozel S, Arciszewski MB. Immunocytochemical detection of calretinin in the claustrum and endopiriform nucleus of the chinchilla. Pol J Vet Sci 2015; 18(4):857-63.

21. Álvarez MI, Lacruz C, Toledano-Díaz A, Monleón E, Monzón M, Badiola JJ Toledano A. Calretinin immunopositive cells and fibers in the cerebellar cortex of normal sheep. Cerebellum 2008; 7(3):417-29.

22. Edmonds B, Reyes R, Schwaller B, Roberts WM. Calretinin modifies presynaptic calcium signaling in frog saccular hair cells. Nat Neurosci 2000; 3(8):786.

23. Turner CP, DeBenedetto D, Liu C. NMDAR blockade-induced neonatal brain injury: Reversal by the calcium channel agonist BayK 8644 . Neurosci Lett 2009; 450(3):292-295.

24. Kara A, Unal D, Simsek N, Yucel A, Yucel N, Selli J. Ultra-structural changes and apoptotic activity in cerebellum of post-menopausal-diabetic rats: a histochemical and ultra-structural study. Gynecol Endocrinol 2014; 30(3):226-231.

25. Coffman KA, Dum RP, Strick PL. Cerebellar vermis is a target of projections from the motor areas in the cerebral cortex. Proc Natl Acad Sci 2011; 108(38):16068-73.

26. Bancroft JD, Gamble M. Theory and Practice of Histological Techniques. Oxford, United Kingdom: Elsevier Health Sciences; 2013.

27. Sarrazy V, Desmouliere A. Double immunohistochemistry with horseradish peroxidase and alkaline phosphatase detection systems: In Histology Protocols. Humana Press, Totowa, NJ; 2010:59-71.

28. Hayat MA. Principles and Techniques of Electron Microscopy: Biological Applications. Cambridge: Cambridge Univ Press 2000; 546-558.

29. Abass MA, Selim SA, Selim AO, El $\square$ Shal AS, Gouda ZA. Effect of orally administered zinc oxide nanoparticles on albino rat thymus and spleen. IUBMB life 2017; 69(7):528-39.

30. Hamza SA, Aly HM, Soliman SO, Abdallah DM. Ultrastrctural study of the effect of zinc oxide nanoparticles on rat parotid salivary glands and the protective role of quercetin. Alexa Dental J 2016; 41:232-237.

31. Pasupuleti S, Alapati S, Ganapathy S, Anumolu G, Pully NR, Prakhya BM. Toxicity of zinc oxide nanoparticles through oral route. Toxicol Indust Health 2012; 28(8): 675-686.

32. Sharma V, Singh P, Pandey AK, Dhawan A. Induction of oxidative stress, DNA damage and apoptosis in mouse liver after sub-acute oral exposure to zinc oxide nanoparticles. Mutat 
Res/ Genetic toxico Environ Mutagensis 2012; 745:84-91.

33. Chung HE, Yu J, Baek M, Lee JA, Kim MS, Kim SH, Maeng EH, Lee JK, Jeong, J, Choi SJ. Toxicokinetics of zinc oxide nanoparticles in rats. Int J Phys:Conference Series 2013; 429(1).

34. Afifi OK. Effect of sodium fluoride on the cerebellar cortex of adult albino rats and the possible protective role of vitamin B6: A light and electron microscopic study. Egypt J Histo 2009; 32:358-67.

35. Azmy AM, Allah MA. Histological study of prolonged exposure to mobile phone radiations on young male albino rats' cerebellar cortex and the role of ginkgo biloba supplementation. J Amer Sci 2013; 9(11):156-66.

36. Shalaby NM, Sarhan NI. Light and electron microscopic study on the effect of valproic acid on cerebellar cortex of adult male albino rats and the possible protective effect of l-carnitine. Egypt J Histo 2008; 256-65.

37. Bisht G, Rayamajhi S. ZnO Nanoparticles: A promising anticancer agent. Nanobiomed 2016; $3: 9$

38. Wang C, Lu J, Zhou L, Li J, Xu J, Li W, Zhang L, Zhong X, Wang T. Effects of long-Term exposure to Zinc oxide nanoparticles on development, Zinc metabolism and biodistribution of minerals ( $\mathrm{Zn}, \mathrm{Fe}$, $\mathrm{Cu}, \mathrm{Mn}$ ) in mice. PloS one 2016; 11(10):e0164434.

39. Abbasalipourkabir R, Moradi H, Zarei S, Asadi S, Salehzadeh A, Ghafourikhosroshahi A, Mortazavi M, Ziamajidi N. Toxicity of zinc oxide nanoparticles on adult male Wistar rats. Food Chem Toxicol 2015; 84:154-160.

40. Guillamón-Vivancos T, Gómez-Pinedo U, MatíasGuiu J. Astrocytes in neurodegenerative diseases (I): function and molecular description. Neurol (Engli Edi) 2015; 30(2):119-129.

41. Rafati A, Erfanizadeh M, Noorafshan A, KarbalayDoust S. Effect of benzene on the cerebellar structure and behavioral characteristics in rats. Asian Pac J Tropi Biomed 2015; 5(7):568-573.

42. Thakur M, Gupta H, Singh D, Mohanty IR, Maheswari U, Vanage G Joshi, DS. Histopathological and ultrastructural effects of nanoparticles on rat testis following 90 days (Chronic study) of repeated oral administration. J Nanobiotechnol 2014; 12(1):1-42.

43. Kumar V, Abbas AK, Fausto N, Aster JC. Robbins and Cotran pathologic basis of disease, professional edition e-book. elsevier health sciences; 2014.
44. El-Dien HM, El Gamal DA, Mubarak HA, Saleh SM. Effect of fluoride on rat cerebellar cortex: light and electron microscopic studies. Egyp J Histo 2010; 33:245-256.

45. Asker SA, Mazroa SA, Sabri Y. Histological and immunohistochemical implications of ketamine protracted doses as a noval candidate in antidepressant treatment on adult rat cerebellar cortex. Int J Adv Res 2016; 4(6):39-50.

46. Bearzatto B, Servais L, Roussel C, Gall D, BabaAïssa F, Schurmans S, d'Exaerde ADK, Cheron G Schiffmann SN. Targeted calretinin expression in granule cells of calretinin-null mice restores normal cerebellar functions. FASEB J 2006; 20(2): 380-382.

47. Toledano A, Álvarez MI, Monleón E, ToledanoDíaz A, Badiola JJ, Monzón M. Changes induced by natural scrapie in the calretinin-immunopositive cells and fibres of the sheep cerebellar cortex. Cerebellum 2012; 11(2):593-604.

48. Byun K, Kim D, Bayarsaikhan E, Oh J, Kim J, Kwak G, Jeong GB, Jo SM, Lee, B. Changes of calcium binding proteins, c-Fos and COX in hippocampal formation and cerebellum of Niemann-Pick, type C mouse. J chem neuroanatomy 2013; 52:1-8.

49. Kamal I, Kamal H. Effects of aluminum on rat cerebellar cortex and the possible protective role of Nigella sativa: a light and electron microscopic study. Egypt J Histol 2013; 36(4):979-990.

50. D“Angelo E, Solinas S, Mapelli J, Gandolfi D, Mapelli L, Prestori F. The cerebellar Golgi cell and spatiotemporal organization of granular layer activity. Front neural circuits 2013; 7:93.

51. Afifi OK, Embaby AS. Histological study on the protective role of ascorbic acid on cadmium induced cerebral cortical neurotoxicity in adult male albino rats. J Microsc Ultrastr 2016; 4(1):3645.

52. Weil MT, Möbius W, Winkler A, Ruhwedel T, Wrzos C, Romanelli E, Bennett JL, Enz L, Goebels N, Nave KA, Kerschensteiner M. Loss of myelin basic protein function triggers myelin breakdown in models of demyelinating diseases. Cell Reports 2016; 16(2):314-22.

53. Alizadeh A, Dyck SM, Karimi-Abdolrezaee S. Myelin damage and repair in pathologic CNS: challenges and prospects. Front mol neurosci $2015 ; 8: 35$.

54. Watenaux B, Rabinowitz T, Needer H, Auderix O Effects of cadmium exposure on the physiology of cerebellar neurone: Progress Neurophysiol 2009; 48:18-24. 
55. Salahuddin N, Galal A. Improving chemotherapy drug delivery by nanoprecision tools :In Nanostructures for Cancer Therapy; 2017: 87-128.

56. Shen C, James SA, de Jonge MD, Turney, TW, Wright PF, Feltis, BN. Relating cytotoxicity, zinc ions, and reactive oxygen in $\mathrm{ZnO}$ nanoparticle- exposed human immune cells. Toxicol sci 2013; 136(1):120-130.

57. Attia H, Nounou H, Shalaby M. Zinc Oxide Nanoparticles Induced Oxidative DNA Damage, Inflammation and Apoptosis in Rat's Brain after Oral Exposure. Toxics 2018; 6(2):1- 29. 
الملخص العربى

\title{
دراسة نسيجية وهستوكميائية مناعية على تأثير جزيئات أكسيد الزنك

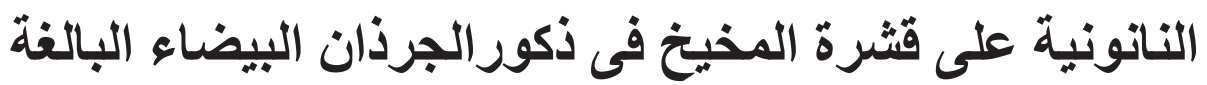

\author{
هبه محمد عبد العزيز، نوره عبد الحميذ مكاوي، نهله السيد ابراهيم

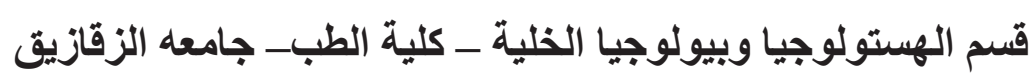

الخلقية: جزيئات أكسيد الزنلك النانونية هي و احدة من جسيمات المعادن الدقيقه التي تستخدم على نطاق واسع في العديد من المجالات هدف الدراسة: هدفت هذه الدراسة إلى التحقق من تأثنير جزيئات أكسيد الزنالك النانونية على قشرة المخيخ من خلال در اسة نسيجية و هستو كيميائية مناعية. المواد والطرق: قسمت ثناثين من ذكور الجرذان البيضاء إلى ثلاث مجمو عات :المجمو عة الاولى (الضابطه), المجمو عة الثانية (المجمو عة المعالجة الاولى ) و التى تلقت50 مجم / كجم من جزيئات أكسيد الزنك النانونية بالفم لمدة شهرين و المجموعة الثالثة (المجموعة المعالجة الثانية) و التى تلقت 200 مجم / كجم من جزيئات أكسيد الزنك النانونية بالفم لمدة شهرين. نم عمل عينات من قثرة المخيخ للار اسة النسيجية والهستوكيميائية مناعية كما تم إجر اء تحليل مورفومتري جني و إحصائي. النتائج: أظهرت المجمو عة المعالجة الاولى خلايا بيركينجى مزدحمة وظهرت باكثر من طبقه محاطة بفر اغات و اضحة ولها نوايا داكنه ، وكثف الفحص الدقيق للخلايا على وجود فجوات سيتوبلازمية و أن الصهاريج لجهاز جولجي

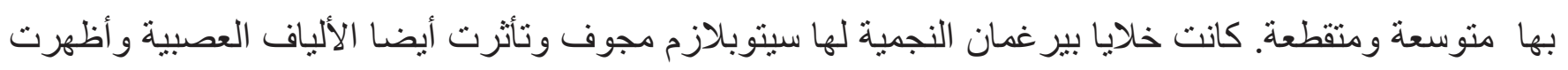
خلل في الطبقات الميلانيه.وكان سيتوبلازم هذه الخلايا إيجابي التفاعل الهستوكميائى المناعى لبروتين كلريتنين. أما المجمو عة الثالثة و التي كانت تدار بجر عة 200 مجم / كجم من جزيئات أكسيد الزنك النانونية أظهرت انتشار و اسع من فن التلف العصبى لدرجة فقد العديد من خلايا بركينجى لتترك فر اغات مكانها. وقد أظهرت در اسة التركيب الدقيق لقشرة المخيخ فى ذات المجموعة أن ميتوكندريا خلايا بيركينيجي بها تكسير فى الحو اجز وبداخلها سيتوبلازم ذات فجوات متعددة. كثفت الخلايا النجمية بير غمان نوى بها مظروف معطوب و غياب العضيات السيتوبلازمية. و علاوة على ذلك ، أظهرت الألياف العصبية مناطق بها فقدان في الطبقات الميلانيه وفجوات سيتوبلازمية. أما التفاعل الهنتوكيائى المناعى لبروتين كلريتنين فى سيتوبلازم خلايا بيركينجى كان سلبيا. الخلاصة: تناول جزيئات أكسيد الزنك النانونية عن طريق الفم تسبب في تغييرات ضيارة مختلفة في البنية النسيجية و الهستوكميائهة مناعية للقشرة المخيخية مما يدل على حدوث السمية العصبية. وهذه التغير ات زادت مع زيادة تناول جزيئات أكسيد الزنائك النانونية. 